Eur. J. Clin. Chem. Clin. Biochem.

Vol. 30, 1992, pp. 319-323

(C) 1992 Walter de Gruyter \& Co.

Berlin - New York

\title{
Filtration and Local Synthesis of Lacrimal Proteins in Acquired Immunodeficiency Syndrome
}

\author{
By Dominique Meillet ${ }^{1}$, P. L. Hoang ${ }^{2}$, F. Unanue ${ }^{2}$, Nathalie Kapel ${ }^{3}$, M.-C. Diemert ${ }^{4}$, Françoise Rousselie ${ }^{2}$, \\ A. Galli ${ }^{1}$ and Jeanne Galli ${ }^{4}$ \\ 1 Laboratoire de Biochimie, Hôpital de la Salpêtrière, Paris, France \\ 2 Service d'Ophtalmologie, Hôpital de la Pitié, Paris, France \\ 3 Laboratoire de Coprologie, Paris, France \\ 4 Laboratoire d'Immunochimie, Paris, France
}

(Received July 16, 1991/March 16, 1992)

Summary: In AIDS the onset of the ocular dry syndrome, characterized by lacrimal hyposecretion and deterioration of the corneal and conjunctival epithelium, generally accompanies the clinical aggravation of immunodepression. The study of serum and lacrimal proteins contributes to our knowledge of the pathophysiology of this syndrome. The lacrimal clearance of albumin indicates changes in the permeability of the haemato-lacrimal and conjunctival barrier. Lacrimal monomeric IgA and $\operatorname{IgG}$ are mainly of plasmatic origin, while polymeric IgA and IgM are synthesized in situ. The concentrations of these analytes thus reflect ocular humoral immune status. They show a strong humoral protein response in patients with cytomegalovirus retinitis. Lacrimal concentrations of lactoferrin and lysozyme were found to be significantly decreased in AIDS patients with ocular dryness, reflecting a decrease in the secretory activity of the lacrimal gland. Moreover, ocular lympho-plasmocyte infiltration was observed in several patients, with an increase in lacrimal $\beta_{2}$-microglobulin concentrations. These various lacrimal proteins could be good markers of the ocular dry syndrome in AIDS.

\section{Introduction}

The incidence of eye disease in patients with the acquired immunodeficiency syndrome (AIDS) is about $63 \%$, according to Holland et al. (1). Approximately $5 \%$ of these patients show an "ocular dry syndrome", characterized by lacrimal hyposecretion associated with deterioration of the corneal and conjunctival epithelium (2). This clinical syndrome often accompanies the aggravation of immunodepression. Indeed, the cytomegalovirus retinitis seems to be correlated with the decrease in the total blood lymphocyte count and the CD4/CD8 $\mathrm{T}$ cell ratio (3).

Battelier et al. showed the interest of studying the various serum and lacrimal proteins for the investigation of the haemato-lacrimal barrier in healthy subjects (4). In the present study we compared the serum and lacrimal protein patterns in healthy subjects and
AIDS patients with or without lacrimal hyposecretion. The proteins studied were immunoglobulins (IgG, IgA, IgM), albumin, $\beta_{2}$-microglobulin, lactoferrin and lysozyme. Our aim was to evaluate the permeability of the lacrimal barrier, local humoral immunity and glandular secretory activity, in order to improve prognosis in AIDS patients with ocular syndrome.

\section{Subjects and Methods \\ Subjects \\ The study involved 18 patients, infected with a human immu- nodeficiency virus (HIV 1). The patients were at stage IV of HIV 1 infection (stage IVB: 2 patients, stage IVC1: 10, stage IVC2: 1, stage IVD: 5) according to the Atlanta Centers for Disease Control criteria (5). The means of the CD4 T cell count and the $\mathrm{CD} 4 / \mathrm{CD} 8$ ratio were $175 \pm 21.5 \times 10^{6} / 1$ and 0.345 \pm 0.043 in the blood of the 18 AIDS patients, respectively.}


Tab. 1. Epidemiologic characteristics of the AIDS patients with and without lacrimal hyposecretion

\begin{tabular}{lll}
\hline & $\begin{array}{l}\text { AIDS with lacrimal hyposecretion } \\
(\mathrm{n}=8)\end{array}$ & $\begin{array}{l}\text { AIDS without lacrimal hyposecretion } \\
(\mathrm{n}=10)\end{array}$ \\
\hline $\begin{array}{l}\text { Age } \\
\text { Sex }\end{array}$ & $\begin{array}{l}44 \pm 13 \text { years }(28-29 \text { years }) \\
\text { all male }\end{array}$ & $\begin{array}{l}36 \pm 13 \text { years }(18-63 \text { years }) \\
\text { all male }\end{array}$ \\
$\begin{array}{l}\text { Major risk factor: } \\
- \text { homosexuality }\end{array}$ & 8 & 8 \\
- iv drug abuse & - & 2 \\
$\begin{array}{l}\text { Schirmer's test } \\
\text { Kaposi's sarcoma }\end{array}$ & $<10 \mathrm{~mm}$ after 5 min & $>10 \mathrm{~mm}$ after 5 min \\
$\begin{array}{l}\text { Opportunistic eye infections: } \\
- \text { Cytomegalovirus retinitis }\end{array}$ & 3 & 3 \\
- ocular candidiasis & 4 & 5 \\
$\begin{array}{l}\text { Administration of } \\
\text { anti-cholinergic drugs }\end{array}$ & - & 1 \\
\hline
\end{tabular}

This patient group was composed of 8 homosexual men aged $44 \pm 13$ years (mean \pm standard error of the mean), with lacrimal hyposecretion (Schirmer test: $<10 \mathrm{~mm}$ after $5 \mathrm{~min}$ ), four of whom presented dry kerato-conjunctivitis and four cases of cytomegalovirus retinitis. The remaining patients were 8 homosexual men and 2 drug abusers $(36 \pm 13$ years) without ocular dryness; 5 had cytomegalovirus retinitis with no apparent degradation of the ocular annex tissues. An ocular biopsy was performed in the AIDS patients. Epidemiologic data are presented in table 1.

\section{Methods \\ Clinical examination}

Lacrimal secretion was measured using Schirmer's test. Keratoconjunctivitis was revealed by the Bengal Rose test.

\section{Tears}

Tears were collected from both eyes after stimulation with 100 $\mathrm{g} / \mathrm{l}$ formaldehyde using microcapillary pipettes, and mixed to form a single pool for each subject. After centrifugation, samples were stored at $-80^{\circ} \mathrm{C}$ until use. The various proteins were measured in the tears and in serum obtained at the same time.

\section{$\operatorname{IgG}, \operatorname{Ig} M$, albumin, lactoferrin and lysozyme measurements}

These proteins were measured in the tears and sera using an electro-immunodiffusion assay with a Multiphor II-(LKB, Sweden) apparatus. The assay was performed with $10 \mathrm{~g} / 1 \mathrm{IEF}$ agarose (Isogel, LKB, Sweden) gel and $10 \mathrm{ml} / \mathrm{l}$ antiserum (anti$\gamma$ chain, anti- $\mu$ chain, anti-lactoferrin, anti-lysozyme (Dako, Denmark) and anti-albumin (Behring, Germany) for the quantitation of IgG, IgM, lactoferrin, lysozyme, and albumin, respectively. The migration buffer was composed of $3 \mathrm{mmol} / \mathrm{l}$ trisaminol, $10 \mathrm{mmol} / \mathrm{l}$ sodium barbital and $5 \mathrm{mmol} / \mathrm{l}$ barbital at $\mathrm{pH}$ 8.4. Diluted or undiluted samples $(3 \mu \mathrm{l})$ were placed on the gel. The assay was run for $18 \mathrm{~h}$ at a potential gradient of $2 \mathrm{~V} / \mathrm{cm}$. The gels were then washed and stained with amidoblack solution. Protein concentrations were determined with reference to specific standards (Behring serum standard for IgG, IgM, albumin and Calbiochem (USA) human milk standard for lactoferrin and lysozyme).

\section{IgA measurement}

Monomeric $\operatorname{IgA}$ and total $\operatorname{IgA}$ were assayed using a modified electro-immunodiffusion method. This technique has been used for colostral IgA and recently for fecal $\operatorname{IgA}(6)$. The assay was run for $18 \mathrm{~h}$ at $+4{ }^{\circ} \mathrm{C}(100 \mathrm{~V})$ in an agarose-polyacrylamide gel, in the presence of a gel barrier which blocks polymeric IgA. The anodic gel contained $4.5 \%$ of anti- $\alpha$ chain antiserum (Dako, Denmark). Samples ( $3 \mu \mathrm{l}$; total protein concentration $<2 \mathrm{~g} / \mathrm{l}$ ) were placed in wells on either side of the blocking gel. For each sample, total and monomeric IgA were determined from the upper and lower wells, respectively. Polymeric IgA levels were calculated as the difference between the two values. Purified human colostral IgA (total IgA: $10 \mathrm{~g} / \mathrm{l}$, polymeric IgA: $8.55 \mathrm{~g} / \mathrm{l}$, monomeric IgA: $1.45 \mathrm{~g} / \mathrm{l}$ ) and calibrated serum (total: IgA $2.0 \mathrm{~g} / \mathrm{l}$ ) were purchased from Behring (Marburg, Germany) and used as standards for lacrimal and serum total IgA, respectively. Purified monoclonal monomeric $\operatorname{IgA}(14.3 \mathrm{~g} / \mathrm{l})$ was used as a standard for the measurement of lacrimal monomeric IgA (6).

\section{$\beta_{2}$-Microglobulin}

$\beta_{2}$-Microglobulin was quantified using a competitive enzymelinked immunosorbent assay (Phadezym, Pharmacia, Sweden).

\section{Presentation of results}

The results of the serum and lacrimal protein assays are expressed in concentration $(\mathrm{g} / \mathrm{l}$ or $\mathrm{mg} / \mathrm{l})$. Albumin clearance was calculated as follows:

Albumin clearance $(\mathrm{ml} / 15 \mathrm{~min})=$

[Lacrimal albumin $(\mathrm{mg} / \mathrm{l}) \times$ Lacrimal output (ml during $15 \mathrm{~min})]$ Serum albumin $(\mathrm{mg} / \mathrm{l})$

A coefficient of excretion was defined for $\operatorname{IgG}$, monomeric $\operatorname{IgA}$, polymeric IgA, IgM, and $\beta_{2}$-microglobulin relative to albumin, which is only filtered through the haemato-lacrimal and conjunctival barrier; its excretion coefficient was arbitrarily taken as one. Jonard also used albumin as a reference protein for intestinal mucosa permeability (8). The coefficient of excretion was calculated as follows:

Lacrimal protein $(\mathrm{mg} / \mathrm{l}) \times$ Serum albumin $(\mathrm{mg} / \mathrm{l})$ Serum protein $(\mathrm{mg} / \mathrm{l}) \times$ Lacrimal albumin $(\mathrm{mg} / \mathrm{l})$ 


\section{Statistical analysis}

For each quantity the results were compared between the three groups using the non-parametric Mann \& Whitney test. Correlations between protein concentrations were identified using the Spearman test.

\section{Results}

\section{Serum proteins}

In the AIDS group with lacrimal hyposecretion, a significant decrease in albumin ( 0.7 times the normal) was observed, with an increase in lysozyme and $\beta_{2^{-}}$ microglobulin (1.4 and 3.1 times the normal, respectively) (tab. 2). In the AIDS group without lacrimal hyposecretion, a similar decrease in albumin was observed, with an increase in total IgA, lactoferrin, lysozyme and $\beta_{2}$-microglobulin $(1.0,1.4,1.7$ and 3.4 times the reference values, respectively). The comparison of results for the two patient groups showed lower serum protein concentrations for IgG, IgA, lactoferrin and lysozyme in the AIDS patients with lacrimal hyposecretion $(\mathrm{p}<0.01)$.

\section{Lacrimal proteins}

Mean values for lacrimal protein concentrations, clearances and protein coefficients of excretion in the patients and healthy subjects are presented in tables 3 and 4 . In the AIDS group with lacrimal hyposecretion, a significant increase was observed in the lacrimal concentration of albumin, monomeric IgA, polymeric $\operatorname{IgA}, \operatorname{IgG}$ and $\beta_{2}$-microglobulin $(4.3,4.1,1.4$, 6.3 and 2.5 times the reference values, respectively). In contrast, lactoferrin and lysozyme concentrations were significantly decreased $(p<0.001)$. Monomeric IgA represented $13 \%$ of total IgA in the patient tears, against $5 \%$ in the healthy subjects. Lacrimal and serum total IgA concentrations were not correlated. Moreover, strong increases in albumin clearance, monomeric IgA and IgM coefficients of excretion (2.7

Tab. 2. Mean concentrations of serum proteins in AIDS patients with and without lacrimal hyposecretion

\begin{tabular}{|c|c|c|c|}
\hline & $\begin{array}{l}\text { AIDS with lacrimal } \\
\text { hyposecretion } \\
(\mathrm{n}=8)\end{array}$ & $\begin{array}{l}\text { AIDS without lacrimal } \\
\text { hyposecretion } \\
(\mathrm{n}=10)\end{array}$ & $\begin{array}{l}\text { Control group } \\
(\mathrm{n}=13)\end{array}$ \\
\hline & $\left.\left.\overline{\mathrm{x}}^{\mathrm{a}}\right) \pm \mathrm{SEM}^{\mathrm{b}}\right)$ & $\bar{x} \pm \operatorname{SEM}$ & $\overline{\mathrm{x}} \pm \mathrm{SEM}$ \\
\hline Albumin $(\mathrm{g} / \mathrm{l})$ & $30.4^{*} \pm 3.9$ & $29.5^{*} \pm 3.0$ & $45.0+6.7$ \\
\hline Total $\operatorname{IgA}(\mathrm{g} / \mathrm{l})$ & $3.85 \pm 0.60$ & $5.40 * \pm 1.20$ & $3.35 \pm 0.50$ \\
\hline Polymeric IgA (g/l) & $0.113 \pm 0.037$ & $0.175^{*} \pm 0.052$ & $0.097 \pm 0.022$ \\
\hline $\operatorname{IgG}(\mathrm{g} / \mathrm{l})$ & $11.4 \pm 1.6$ & $17.0 \pm 2.1$ & $14.9 \pm 1.4$ \\
\hline $\operatorname{IgM}(\mathrm{g} / \mathrm{l})$ & $1.65 \pm 0.40$ & \pm 0.55 & $1.90 \pm 0.25$ \\
\hline Lactoferrin (mg/l) & $1.3 \pm 1.3$ & \pm 1.9 & $1.5 \pm 0.1$ \\
\hline Lysozyme (mg/l) & $10.6^{*} \pm 2.0$ & $3.1 \pm 2.2$ & $7.5 \pm 0.8$ \\
\hline$\beta_{2}$-microglobulin $(\mathrm{mg} / \mathrm{l})$ & $4.27 * * \pm 0.70$ & $4.65^{* *} \pm 0.80$ & $1.38 \pm 0.1$ \\
\hline
\end{tabular}

a) Mean values

b) Standard error of the mean

Statistical comparison between the mean serum protein concentrations in patient and control groups $\left({ }^{*} \mathrm{p}<0.01,{ }^{* *} \mathrm{p}<0.001\right)$

Tab. 3. Mean concentrations of lacrimal proteins in AIDS patients with and without lacrimal hyposecretion

\begin{tabular}{|c|c|c|c|}
\hline \multirow[b]{3}{*}{ Albumin (mg/l) } & \multirow{2}{*}{$\begin{array}{l}\text { AIDS with lacrimal } \\
\text { hyposecretion } \\
(\mathrm{n}=8) \\
\overline{\mathrm{x}} \pm \text { SEM }\end{array}$} & \multirow{2}{*}{$\begin{array}{l}\text { AIDS without lacrimal } \\
\text { hyposecretion } \\
(\mathrm{n}=10) \\
\overline{\mathrm{x}} \pm \mathrm{SEM}\end{array}$} & $\begin{array}{l}\text { Control group } \\
(\mathrm{n}=13)\end{array}$ \\
\hline & & & $\overline{\mathrm{x}} \pm \mathrm{SEM}$ \\
\hline & $86^{* *} \pm 36$ & $59^{* *} \pm 26$ & \pm 3 \\
\hline Total IgA (mg/l) & $506 \pm 153$ & $539 \pm 123$ & $328 \pm 61$ \\
\hline Monomeric IgA (mg/l) & $66 \pm 23$ & $49^{* *} \pm 15$ & $16 \pm 3$ \\
\hline Polymeric $\operatorname{IgA}(\mathrm{mg} / \mathrm{l})$ & $440 * \pm 133$ & $490 \pm 112$ & $312 \pm 58$ \\
\hline $\operatorname{IgG}(\mathrm{mg} / \mathrm{l})$ & $13 \pm 5$ & $9 \pm 4$ & $\pm \quad 1$ \\
\hline $\operatorname{IgM}(\mathrm{mg} / \mathrm{l})$ & $57^{* *} \pm 23$ & $42^{* *} \pm 18$ & \pm \\
\hline Lactoferrin (mg/l) & $31^{* *} \pm 14$ & $20 * * \pm 6$ & \pm 1 \\
\hline Lysozyme $(\mathrm{mg} / \mathrm{l})$ & $1402 * * \pm 362$ & $3066 \pm 533$ & \pm 414 \\
\hline$\beta_{2}$-microglobulin $(\mathrm{mg} / \mathrm{l})$ & $958 * * \pm 166$ & $1467 \pm 209$ & $1699 \pm 213$ \\
\hline & $27.7^{* *} \pm \quad 4.4$ & $28^{* *} \pm 2.8$ & $11.1 \pm 1.3$ \\
\hline
\end{tabular}

$* \mathrm{p}<0.01^{* *} \mathrm{p}<0.001$ 
Tab. 4. Clearance and excretion coefficient of various proteins relative to albumin in AIDS patients with or without lacrimal hyposecretion

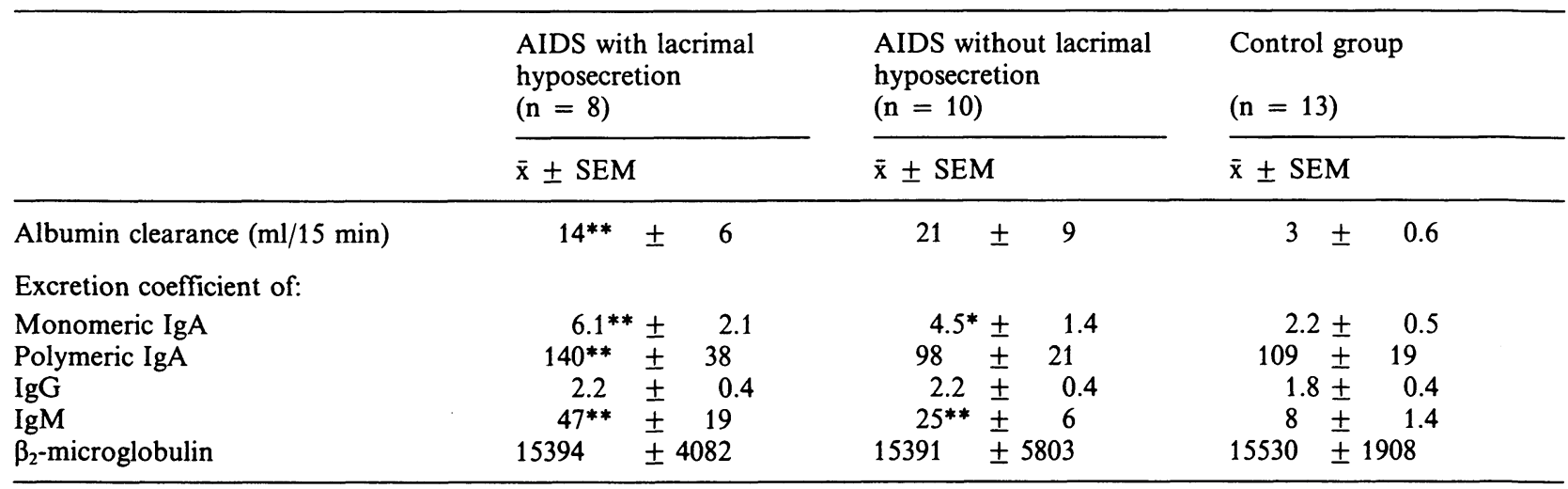

$* \mathrm{p}<0.01^{* *} \mathrm{p}<0.001$

and 5.9 times the reference values, respectively) were observed.

In the AIDS group without lacrimal hyposecretion the strongest lacrimal modifications were in albumin, monomeric $\operatorname{IgA}$, polymeric $\operatorname{IgA}, \operatorname{IgG}, \operatorname{IgM}$ and $\beta_{2^{-}}$ microglobulin $(3.0,3.1,1.6,4.4,4.0$ and 2.5 times the reference values, respectively). Monomeric IgA represented $9 \%$ of total IgA in the tears. Albumin clearance, monomeric IgA and IgM coefficients of excretion, polymeric $\operatorname{IgA} /$ total $\operatorname{IgA}$ were significantly increased $(7.0,2.0,1.8$ and 3.1 times the reference values, respectively). However, no significant difference in lactoferrin and lysozyme concentrations was observed between the patient and control groups.

A positive correlation was observed in each patient group between the increase in lacrimal albumin, monomeric $\operatorname{IgA}$ and $\operatorname{IgG}$ concentrations $(\mathrm{p}<0.01)$ and between IgG and $\operatorname{IgM}(\mathrm{p}<0.01)$. Lacrimal IgA and IgM concentrations were not intercorrelated. The increases in lacrimal IgA, IgG and IgM concentrations were correlated with the decrease in lactoferrin and lysozyme concentrations in the AIDS group with lacrimal hyposecretion $(\mathrm{p}<0.01)$.

\section{Discussion}

We used two electroimmunoassays to study the main serum and lacrimal proteins in man. The first can be used to quantify albumin, $\operatorname{IgG}, \operatorname{IgM}$, lactoferrin and lysozyme and uses only one type of gel and one buffer for the various proteins, except for lysozyme which requires a $\mathrm{pH}$ of 9.5 . The second, a modified electroimmunodiffusion assay, permits the simultaneous measurement of lacrimal monomeric $\operatorname{IgA}$ and total IgA (6). A colostral IgA standard is used to determine lacrimal total $\operatorname{IgA}$; under these conditions, no correc- tion factor is necessary. The measurement of lacrimal monomeric IgA requires a serum monomeric IgA standard. This assay is relatively simple and easy to adapt to routine use and is reliable, linear $(5-200$ $\mathrm{mg} / \mathrm{l})$ and reproducible $(<10 \%)$. In AIDS patients, the increase in albumin clearance indicates transsudation of plasma proteins related to an ocular inflammation, as previously observed by Van Bijsterveld \& Liotet et al. in non-AIDS patients with dry keratoconjunctivitis $(9,10)$. The high concentrations of serum $\beta_{2}$-microglobulin and IgA in AIDS patients indicate lympho-plasmocyte stimulation related to HIV 1 infection or opportunistic agents. This seems to be associated with a poor short-term vital prognosis (11). Lacrimal IgG concentration and IgG coefficient of excretion show that this protein, which has a larger hydrodynamic radius $(5.34 \mathrm{~nm})$ than albumin $(3.58$ $\mathrm{nm}$ ), is mainly derived from the plasma by passive transport, although small amounts of IgG can be synthesized locally (4). The increase in lacrimal total IgA concentration in AIDS is mainly due to high local polymeric IgA synthesis and to the transfer of plasma monomeric IgA $(5.4 \mathrm{~nm})$ into the tears by ocular inflammation (12). Moreover, the higher monomeric IgA coefficient of excretion relative to that of IgG in AIDS with or without lacrimal hyposecretion suggests possible ocular monomeric IgA synthesis. Secretory polymeric IgA indicate ocular immune stimulation and probably a general secretory immune response. Indeed, Montgomery et al. showed that lacrimal antibody-producing cells arise in central mucosal sites such as the gastro-intestinal tract (13). The increase in lacrimal IgM $(12.0 \mathrm{~nm})$ concentrations and IgM coefficient of excretion in the AIDS patients reflects a primary local immune response, although a small amount of lacrimal IgM can derive from a plasmatic transsudation mechanism (14). The increase in lacrimal immunoglobulins might be related to a 
concomitant infection of the conjunctiva or the lacrimal gland by cytomegalovirus, observed in many of our AIDS patients. This observation has been also reported by England et al. in an immunologically competent adult (15).

Lactoferrin and lysozyme levels reflect the secretory activity of the lacrimal and annex glands $(16,17)$. In AIDS patients with lacrimal hyposecretion, the decrease in these two proteins in the tears indicates an alteration of glandular secretion. This phenomenon is also observed in kerato-conjunctivitis sicca in nonAIDS patients (18). The high value of the $\beta_{2}$-microglobulin coefficient of excretion and the difference in the relative molecular masses of $\beta_{2}$-microglobulin $\left(M_{\mathrm{r}}=11800\right)$ and albumin $\left(M_{\mathrm{r}}=60000\right)$ clearly reflects local synthesis. In the AIDS patients, the lacrimal $\beta_{2}$-microglobulin concentration was correlated

\section{References}

1. Holland, G. N., Pepose, J. S., Petit, T. H., Gottlieb, A. S. \& Foss, R. Y. (1983) Acquired immune deficiency syndrome. Ocular manifestation. Ophthalmology 90, 859873.

2. Le Hoang, P., Girard, B. \& Rousselie, F. (1989) Oeil et SIDA. Ophtalmologie 3 (5) Suppl. 1, 1-92.

3. Palestine, A. G., Rodrigues, M. M. \& Macher, A. M. (1984) Ophthalmic involvement in acquired immunodeficiency syndrome. Ophthalmology 91, 1092-1099.

4. Batellier, L., Chaumeil, C. \& Moens, C. (1988) Passage des protéines à travers la barrière hémato-lacrymale. Ophtalmologie 2, $111-113$.

5. Centers for Disease Control, US department of health and Human Services; Atlanta, Georgia (1986) Classification system for T-lymphotropic virus type III/lymphadenopathy-associated virus infection. Ann. Intern. Med. 105, $234-$ 237.

6. Meillet, D., Raichvarg, D., Tallet, F., Savel, J., Yonger, J. \& Gobert, J. G. (1987) Measurement of total monomeric and polymeric IgA in human faeces by electroimmunodiffusion. Clin. Exp. Immunol. 69, 142-147.

7. Fine, J. M. \& Steinbuch, M. (1970) A simple technique for the isolation of monoclonal IgG and IgA. Rev. Eur. Clin. Biol. 15, 1115-1121.

8. Jonard, P. P., Rambaud, J. C., Dive, C., Vaerman, J. P., Gallian, A. \& Delacroix, D. L. (1984) Secretion of immunoglobulins and plasma proteins from the jejunal mucosa. Transport rate and origin of polymeric immunoglobulin $\mathrm{A}$. J. Clin. Invest. 74, 525-535.

9. Liotet, S., Warnet, V. N. \& Schroeder, A. (1982) Etude de la barrière hémato-lacrymale humaine normale. J. Fr. Ophtalmol. 5, 707-710. with a lympho-plasmocytic ocular infiltration. Thus simultaneous study of serum and lacrimal proteins in AIDS indicates several abnormalities notably in AIDS patients with lacrimal hyposecretion. A viral infection itself could be responsible for these phenomena, but AIDS patients generally take anxiolytic drugs with an anti-cholinergic effect, making it difficult to attribute all these observations to ocular opportunistic infections. Study of the anti-cytomegalovirus- and anti-HIV 1-specific immune response in serum and lacrimal fluid of AIDS patients could help to identify the role of these viruses in the pathophysiology of ocular dry syndrome.

\section{Acknowledgements}

We thank $C$. Hervé for technical assistance and $C$. Hapiot and M. C. Esposito for preparation of the manuscript.

10. Van Bijsterveld, O. P. \& Ekdom, B. (1984) Surface tension of lacrimal fluid in patients with kerato-conjunctivitis sicca. Ophthalmologica 188, 44-45.

11. Lefrère, J. J., Fine, J. M., Lambin, P., Salmon, D. \& Salmon, C. (1988) Increased IgA as predictor of development of AIDS en HIV-infected subjects. Clin. Chem. 34, 1356.

12. Allansmith, M. R., Radl, J., Haaijman, J. J. \& Mestecky, J. (1985) Molecular forms of tear IgA and distribution of IgA subclasses in human lacrimal glands. J. Allergol. Clin. Immunol. 76, 569-576.

13. Montgomery, P. C., Rockey, J. H., Majumbar, A. S., Lemaitre-Coelho, I. M., Vaerman, J. P. \& Avylidiz, A. (1984) Parameters influencing the expression of IgA antibodies in tears. Invest. Ophthalmol. Vis. Sci. 24, 369-373.

14. Janssen, P. T. \& Van Bijsterveld, O. P. (1983) Origin and biosynthesis of human tear fluid proteins. Invest. Ophthalmol. Vis. Sci. 5, 623-630.

15. England, A. C., Miller, S. A. \& Maki, D. G. (1982) Ocular findings in acute cytomegalovirus infection in an immunologically competent adult. N. Engl. J. Med. 307, 94-95.

16. Gillette, T. E. \& Allansmith, M. R. (1980) Lactoferrin in human ocular tissues. Am. J. Ophthalmol. 90, 30-37.

17. Gillette, T. E., Greiner, J. V. \& Allansmith, M. R. (1981) Immuno-histochemical localization of human tear lysozyme. Arch. Ophthalmol. 99, 298-300.

18. Liotet, S., Van Bijsterveld, O. P., Chomette, O., Moulis, R. \& Arrata, M. (1987) L'oeil sec. In: Masson Ed. Rapport de la Société Française d'Ophtalmologie, Paris, New York, Barcelona, Milan, Mexico, Sâo Paulo, 400 pp.
Dr D. Meillet
Laboratoire de Biochimie
Hôpital de la Salpêtrière
47, Boulevard de l'Hôpital
F-75013 Paris 
